\title{
KAJIAN PUSTAKA PENGARUH SUHU DAN KONSENTRASI TERHADAP PROSES PEMISAHAN NIKEL DARI LOGAM PENGOTOR MENGGUNAKAN METODE LEACHING
}

\author{
Ade Yanti Nurfaidah ${ }^{1}$, Dheana Putri Lestari ${ }^{1}$, Rheisya Talitha Azzahra ${ }^{1}$, Dian \\ Ratna Suminar ${ }^{1, *}$ \\ ${ }^{1}$ Jurusan Teknik Kimia, Politeknik Negeri Bandung, Indonesia \\ *E-mail: dian.ratna@polban.ac.id
}

\begin{abstract}
Abstrak
Nikel merupakan unsur logam yang penggunaannya sudah dikenal dalam industri, terutama pada pelapisan logam dan paduan. Pengolahan nikel dari bijih nikel laterit (jenis Limonit) menggunakan proses hidrometalurgi Atmospheric Pressure Acid Leaching (APAL) yang dinilai lebih ekonomis karena pemakaian energi dan biaya operasional cukup rendah. Media pelarut yang digunakan berupa larutan asam sulfat $\left(\mathrm{H}_{2} \mathrm{SO}_{4}\right)$. Sebelum dilakukan pengolahan, karakterisasi bijih dilakukan menggunakan X-Ray Diffraction (XRD), X-Ray Flourscence (XRF), dan Scanning Electron Microscopy (SEM). Metode penelitian yang dilakukan yaitu literature review. Hasil review dari beberapa artikel jurnal menunjukkan bahwa kadar nikel yang terkandung pada suatu bijih sekitar 1,42\%, 2,94 dan 0,95\% serta sisanya adalah pengotor. Kondisi operasi yang tepat akan menghasilkan pemurnian nikel yang cukup tinggi. Parameter kondisi operasi yang dapat memengaruhi proses pemisahan nikel diantaranya suhu operasi yang ditunjukan dengan semakin meningkatnya \% ekstraksi nikel seiring dengan kenaikan suhu. Selain suhu operasi, konsentrasi pelarut juga salah satu parameter yang mempengaruhi \% ekstraksi karena semakin tinggi ion $\mathrm{H}^{+}$ akan memudahkan proses pelarutan sehingga akan mengikat Nikel Oksida yang terdapat pada bijih. Suhu paling optimal untuk menghasilkan nikel dengan kemurnian tinggi dalam operasi pelindian atmosferik adalah $90^{\circ} \mathrm{C}$ dan konsentrasi asam sulfat $5 \mathrm{M}$.
\end{abstract}

Kata Kunci: Nikel, pelindian, suhu, konsentrasi

\begin{abstract}
Nickel is a metal element whose use is well known in industry, especially in metal and alloy plating. The processing of nickel from laterite nickel ore (Limonite type) uses a hydrometallurgical process of Atmospheric Pressure Acid Leaching (APAL) which is considered more economical because energy consumption and operational costs are quite low. The solvent medium used is a solution of sulfuric acid $\left(\mathrm{H}_{2} \mathrm{SO}_{4}\right)$. Prior to processing, ore characterization was carried out using X-Ray Diffraction (XRD), X-Ray Flourscence (XRF), and Scanning Electron Microscopy (SEM). The research method literature review article. The results of reviews from several journal articles show that the nickel content contained in an ore is around $1.42 \%, 2.94 \%$ and $0.95 \%$ and the rest is impurity. The right operating conditions will result in relatively high nickel refining. The operating condition parameters that can affect the nickel separation process include the operating temperature which is indicated by the increasing \% nickel extraction along with the increase in temperature. In addition to operating temperature, solvent concentration is also one of the parameters that affects the\% extraction because the higher the $\mathrm{H}^{+}$ion will facilitate the dissolving process so that it will bind to the Nickel Oxide contained in the ore. The optimal temperature to produce high-purity nickel in atmospheric leaching operations is $90^{\circ} \mathrm{C}$ and a sulfuric acid concentration of $5 \mathrm{M}$.
\end{abstract}

Keywords: Nickel, leaching, temperature, concentration 


\section{PENDAHULUAN}

Nikel merupakan salah satu unsur logam yang penggunaannya telah dikenal dalam industri. Logam ini banyak digunakan karena memiliki ketahanan yang baik terhadap korosi, mudah dibentuk tetapi tetap kuat, serta katalisator dan konduktor yang baik. Sekitar $60 \%$ sumber nikel yang ada di dunia tersedia dalam wujud nikel oksida, atau yang biasa disebut nikel laterit, sedangkan $40 \%$ sisanya berbentuk endapan sulfida. Secara umum, bijih laterit diklasifikasikan menjadi dua jenis, yaitu limonit dan saprolit. Bijih saprolit memiliki kadar nikel sebesar 1.5-3.0\% dan bijih limonit sebesar 1.0-1.5\% (Wahyuadi dan Adiyanto, 2016).

Pengolahan bijih nikel berkadar tinggi diproses melalui proses temperatur tinggi (pirometalurgi), sedangkan ekstraksi nikel dari bijih nikel laterit berkadar rendah umumnya dilakukan dengan cara hidrometalurgi, karena bila diolah dengan proses pirometalurgi, dinilai tidak ekonomis dan nikel yang dihasilkan memiliki grade yang rendah (Solihin dan Firdiyono, 2014). Selain itu, Wanta, dkk (2018) mengatakan bahwa proses hidrometalurgi memiliki keunggulan yaitu menghasilkan produk yang jauh lebih murni dibanding proses pirometalurgi. Proses hidrometalurgi yang digunakan untuk pengolahan nikel laterit yaitu proses Caron, proses High Pressure Acid Leaching, dan proses Atmospheric Pressure Acid Leaching (Kyle, 2010 dalam Wanta, dkk., 2018). Dari ketiga proses tersebut, metode APAL dinilai lebih ekonomis bila diaplikasikan pada industri, karena proses ini mengunakan tekanan atmosfer, sehingga membutuhkan biaya operasional dan energi yang lebih rendah (McDonald dan Whittington, 2008; Habbache, dkk., 2009 dalam Wanta, dkk., 2018). Hasil akhir dari proses hidrometalurgi nikel laterit adalah logam murni yang kualitasnya sama dengan intermediate products.

Dalam proses leaching, larutan yang digunakan biasanya adalah asam sufat, asam nitrat dan asam klorida. Selain dari proses yang digunakan, kualitas dan banyaknya nikel yang dihasilkan juga dipengaruhi oleh faktor lain, contohnya yaitu suhu dan konsentrasi larutan yang digunakan dalam pelindian atau leaching. Fathoni dan Mubarok, (2015); Astuti, dkk., (2016) dalam Wanta, dkk., (2018) menjelaskan bahwa secara teoritis, semakin tinggi suhu yang digunakan, maka semakin banyak pula nikel yang didapatkan. Dalam percobaan yang dilakukan oleh Wanta, dkk., (2018), disebutkan pula bahwa konsentrasi larutan yang digunakan dalam proses leaching dapat memengaruhi banyaknya produk yang dihasilkan. Pada penelitian kali ini, akan membahas literature review tentang pengaruh suhu dan konsentrasi terhadap proses pemisahan nikel dari logam pengotor menggunakan metode leaching untuk mengetahui kondisi operasi yang efisien untuk menghasilkan \% ekstraksi nikel yang tinggi.

\section{METODE PENELITIAN}

\section{Identifikasi Masalah}

Tahapan identifikasi masalah dilakulan dengan mencari beberapa sumber yang berkaitan dengan bagaimana memisahkan nikel dari logam-logam pengotor pada nikel ore menggunakan proses leaching. Parameter yang digunakan untuk meneliti proses leaching nikel ore ini yaitu pengaruh konsentrasi reagen yang digunakan dan pengaruh suhu saat proses leaching berlangsung. 


\section{Pengumpulan Data}

Pengumpulan data dalam tahap ini dilakukan dengan mencari literatur. Sumber-sumber utama yang dijadikan acuan terlampir pada tabel berikut :

Tabel 1. Daftar Artikel Yang Ditinjau

\begin{tabular}{|c|c|c|}
\hline No & Penulis & Kondisi Operasi \\
\hline 1. & $\begin{array}{l}\text { Eni Febriana, } \\
\text { Agung } \\
\text { Tristiyan, } \\
\text { Wahyu } \\
\text { Mayangsari, } \\
\text { dan Agus Budi } \\
\text { Prasetyo } \\
\text { (2018) }\end{array}$ & $\begin{array}{l}\text { Konsentrasi asam sulfat } \\
\text { sebesar } 1 \mathrm{M} \text {, dengan } \\
\text { waktu } 480 \text { menit pada } \\
\text { suhu } 30,50 \text {, dan } 90{ }^{\circ} \mathrm{C} \\
\text { dan kecepatan } \\
\text { pengadukan } 400 \mathrm{rpm}\end{array}$ \\
\hline 2. & $\begin{array}{l}\text { Sepideh } \\
\text { Javanshir, } \\
\text { Zahra Heidari } \\
\text { Mofrad, dan } \\
\text { Ahmad } \\
\text { Azargoon } \\
(2018)\end{array}$ & $\begin{array}{l}\text { Konsentrasi asam sulfat } \\
\text { sebesar 2-5 } \mathrm{M} \text {, dengan } \\
\text { waktu } 120 \text { menit pada } \\
\text { temperatur } 45-90 \quad{ }^{\circ} \mathrm{C} \\
\text { dengan } \\
\text { pecepatan } \\
\text { pengadukan } 300 \mathrm{rpm}\end{array}$ \\
\hline 3. & $\begin{array}{l}\text { Petrovski A, } \\
\text { Nacevski G, } \\
\text { Dimitrov A.T, } \\
\text { dan } \\
\text { Paunovic.P } \\
(2019)\end{array}$ & $\begin{array}{l}\text { Variasi konsentrasi } \\
\text { asam sulfat pada } 0.5,1 \text {, } \\
\text { dan } 3 \mathrm{M} \text {, dengan variasi } \\
\text { waktu } 15,30,60 \text { dan } 120 \\
\text { menit serta pada suhu } \\
25,50 \text { dan } 90^{\circ} \mathrm{C} \text { dengan } \\
\text { kecepatan pengadukan } \\
600 \mathrm{rpm}\end{array}$ \\
\hline 4. & $\begin{array}{l}\text { Kevin Cleary } \\
\text { Wanta, Ratna } \\
\text { Frida Susanti, } \\
\text { Robert } \\
\text { Kurniawan } \\
\text { Budi Santoso, } \\
\text { dan Felisha } \\
\text { Hapsari } \\
\text { Tanujaya } \\
\text { (2017) }\end{array}$ & $\begin{array}{l}\text { Konsentrasi asam sulfat } \\
\text { sebesar } 0,1 \mathrm{M} \text {, dengan } \\
\text { waktu } 120 \text { menit pada } \\
\text { suhu } 30,60 \text {, dan } 85{ }^{\circ} \mathrm{C} \\
\text { dipanaskan dalam labu } \\
\text { leher tiga }\end{array}$ \\
\hline 5. & $\begin{array}{l}\text { Batnasan } \\
\text { Altansukh, } \\
\text { Kazutoshi } \\
\text { Haga, dan } \\
\text { Atsushi } \\
\text { Shibayama. } \\
\text { (2014) }\end{array}$ & $\begin{array}{l}\text { Konsentrasi asam sulfat } \\
\text { sebesar } 1-4 \mathrm{M} \text {, dengan } \\
\text { waktu } 120-480 \text { menit } \\
\text { pada suhu } 60-95{ }^{\circ} \mathrm{C} \\
\text { dengan kecepatan } \\
\text { pengadukan } 500 \mathrm{rpm}\end{array}$ \\
\hline 6. & $\begin{array}{lr}\text { Wei } & \text { Luo, } \\
\text { Qiming } & \text { Feng, } \\
\text { Leming } & \text { Ou, }\end{array}$ & $\begin{array}{l}\text { Konsentrasi asam } 10 \% \\
( \pm 2 \mathrm{M})\end{array} \begin{array}{l}\text { kecepatan } \\
\text { pengadukan } 500 \mathrm{rpm},\end{array}$ \\
\hline
\end{tabular}

\begin{tabular}{|c|c|c|}
\hline No & Penulis & Kondisi Operasi \\
\hline & Guofan & $\begin{array}{lll}\text { padatan } & 25 & \text { mesh, }\end{array}$ \\
\hline & Zhang, dan Yu & dengan waktu 5 menit \\
\hline & Chen (2010) & $\begin{array}{l}\text { dan variasi suhu } 70,80 \text {, } \\
\text { dan } 90^{\circ} \mathrm{C}\end{array}$ \\
\hline \multirow[t]{5}{*}{7.} & Buyukakinci, & Variasi Konsentrasi \\
\hline & E dan Topyaka & asam $2 \mathrm{~N}, 4 \mathrm{~N}$, dan $5 \mathrm{~N}(1$ \\
\hline & Y.A (2009) & $\begin{array}{l}\mathrm{M}, 2 \mathrm{M} \text { dan } 2,5 \mathrm{M}) \\
\text { variasi suhu } 25^{\circ} \mathrm{C}, 50^{\circ} \mathrm{C} \text {, }\end{array}$ \\
\hline & & $\begin{array}{l}75^{\circ} \mathrm{C} \text {, dan } 95^{\circ} \mathrm{C} \text {; ukuran } \\
\text { partikel } 0,074 \mathrm{~mm} \text { dan } \\
\text { data waktu yang diambil }\end{array}$ \\
\hline & & 24 jam. \\
\hline \multirow[t]{8}{*}{8.} & Abolfazl & Variasi suhu pelindian \\
\hline & Hossenini, & $25^{\circ} \mathrm{C}, \quad 40^{\circ} \mathrm{C}, \quad 60^{\circ} \mathrm{C}$ dan \\
\hline & Shahram & $80^{\circ} \mathrm{C}$ dengan ukuran \\
\hline & Raygan, & partikel rentang $180-250$ \\
\hline & Ahmad & $\mathrm{mm}$ waktu 240 menit \\
\hline & Rezaei, & dan variasi konsentrasi \\
\hline & Ali Jafari & dalam satuan mol \\
\hline & (2017) & 1,2,3,4 mol. \\
\hline \multirow[t]{4}{*}{9.} & Abdurrahman & Ukuran partikel 200 \\
\hline & Hanif Fadilah & mesh, suhu $95^{\circ} \mathrm{C}$, waktu \\
\hline & (2020) & pelindian 6 jam dan \\
\hline & & $\begin{array}{l}\text { sulfat sebesar } 3 \mathrm{M}, 4 \mathrm{M} \\
\text { dan } 5 \mathrm{M} \text {. }\end{array}$ \\
\hline \multirow[t]{5}{*}{10.} & Sri Yulianti & Suhu pelindian $90^{\circ} \mathrm{C}$, \\
\hline & $(2020)$ & ukuran partikel $\leq 200$ \\
\hline & & mesh, pelindian 4-6 jam \\
\hline & & dan variasi konsentrasi \\
\hline & & $\begin{array}{l}\text { asam sulfat } 5 \mathrm{M} \text { dan } 6 \\
\mathrm{M} \text {. }\end{array}$ \\
\hline
\end{tabular}

\section{Penyusunan artikel literature review}

Berdasarkan data yang diperoleh dari beberapa artikel jurnal ilmiah yang dijadikan acuan, analisis dilakukan dan dilakukan pengolahan data untuk membahas hasil apa saja yang dicapai dalam penelitian ini

\section{Mekanisme Proses Leaching}

Mekanisme proses leaching dalam percobaan ini disadur dari salah satu sumber artikel rujukan penelitian. Wanta, dkk (2018) menjelaskan bahwa alat untuk percobaan dirangkai sesuai dengan Gambar 1. Larutan $\mathrm{H}_{2} \mathrm{SO}_{4}$ 
kemudian dimasukkan ke dalam labu leher tiga serta dipanaskan hingga mencapai suhu yang telah ditentukan. Konsentrasi pelarut dan suhu divariasikan menjadi beberapa varian, yaitu 2M, 5M, dan $7 \mathrm{M}$ untuk konsentrasi pelarut (Javanshir, dkk., 2018) serta 30, 50 dan $90^{\circ} \mathrm{C}$ untuk temperatur pelindian (Febriana, dkk., 2018).

Sampel nikel laterit dimasukkan ke dalam labu sesuai dengan perbandingan solid liquid yang ditetapkan. Sampel diambil setiap 10 menit sekali sebanyak $5 \mathrm{~mL}$ selama proses leaching berjalan. Setelah itu dilakukan analisis sampel. Sampel hasil leaching diberi perlakuan berupa pemisahan menggunakan centrifuge. Supernatan dituangkan ke dalam botol sedangkan residu dioven. Supernatan dan pengukuran hasil \%ekstraksi nikel dianalisis menggunakan alat Atomic Absorption Spectroscopy (AAS).

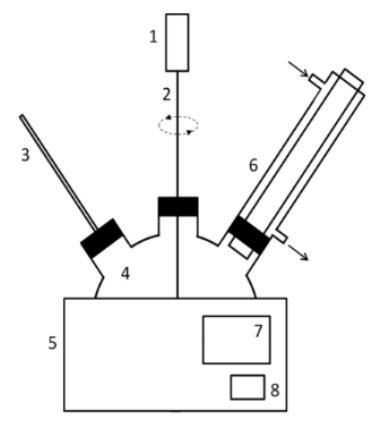

$$
\begin{aligned}
& \text { Keterangan: } \\
& \text { 1. Motor pengaduk } \\
& \text { 2. Pengaduk merkuri } \\
& \text { 3. Termometer } \\
& \text { 4. Labu leher tiga } \\
& \text { 5. Waterbath } \\
& \text { 6. Pendingin balik } \\
& \text { 7. Pengatur suhu } \\
& \text { 8. Tombol on/off } \\
& \rightarrow \text { Aliran air pendingin }
\end{aligned}
$$

Gambar 1. Rangkaian alat leaching. Sumber : Wanta, dkk (2018)

\section{HASIL DAN PEMBAHASAN}

Sebelum dilakukan pengolahan, karakterisasi bijih dilakukan menggunakan XRD (x-ray diffraction), XRF ( $x$-ray flourscence), dan SEM (scanning electron microscopy). Berikut dilampirkan komposisi bijih nikel setelah dilakukan karakterisasi, seperti pada Tabel 2-4.
Tabel 2. Komposisi Bijih Nikel Laterit (Jenis Limonit) dari Halmahera, Maluku Utara

\begin{tabular}{lc}
\hline \multicolumn{1}{c}{ Komposisi } & Kadar (\%) \\
\hline Besi Oksida & 69,6 \\
Nikel Oksida & 1,42 \\
$\mathrm{SiO}_{2}$ & 14,8 \\
$\mathrm{Al}_{2} \mathrm{O}_{3}$ & 4,63 \\
$\mathrm{MgO}$ & 3,04 \\
\hline
\end{tabular}

Sumber: Febriana, dkk (2018).

Tabel 3. Komposisi Bijih Nikel Laterit (Jenis Limonit) dari Pomalaa, Sulawesi Tenggara

\begin{tabular}{cc}
\hline Komposisi & Kadar $(\%)$ \\
\hline $\mathrm{Fe}$ & 79,8 \\
$\mathrm{Si}$ & 6,31 \\
$\mathrm{Mg}$ & 0,94 \\
$\mathrm{Ni}$ & 2,94 \\
$\mathrm{Cr}$ & 2,84 \\
$\mathrm{Co}$ & 0,13 \\
\hline
\end{tabular}

Sumber: Wanta, dkk. (2017).

Tabel 4. Komposisi Bijih Nikel Laterit (Jenis Limonit) dari Papua Nugini

\begin{tabular}{cc}
\hline Komposisi & Kadar $(\%)$ \\
\hline $\mathrm{Fe}$ & 48,12 \\
$\mathrm{Al}$ & 1,8 \\
$\mathrm{Ni}$ & 0,95 \\
$\mathrm{Cr}$ & 0,29 \\
$\mathrm{Co}$ & 0,07 \\
$\mathrm{Mg}$ & 0,15 \\
\hline Sumber: Altansukh, Batnasan dkk. (2014).
\end{tabular}

Berdasarkan tabel perbandingan beberapa sumber, dapat diamati bahwa kadar nikel dalam suatu bijih sangat sedikit sekali, yaitu sekitar 1,42\%, $2.94 \%$ dan yang lainnya menunjukkan $0,95 \%$ (semua dalam satuan \%-massa), sehingga untuk memurnikan nikel tersebut membutuhkan suatu metode leaching yang efisien. Luo, dkk (2010) dalam Febriana, dkk (2018) menyatakan bahwa untuk pelindian saprolit (jenis laterit), asam sulfat adalah asam yang paling efisien dibandingkan dengan yang lain. Asam sulfat $10 \%(\mathrm{v} / \mathrm{v})$ cukup korosif untuk mengubah struktur lizardit 
karena nikel dan lizardit memiliki ikatan yang longgar dengan lapisan oktahedral, sehingga mampu melarutkan nikel karena jumlah ion $\mathrm{H}^{+}$nya lebih banyak dari asam yang lain.

Terdapat beberapa parameter yang dapat memengaruhi proses leaching pada pelarutan nikel supaya dapat terpisah dari logam pengotor, salah satunya yaitu suhu.

Dari Gambar 2 terlihat bahwa kenaikan suhu menyebabkan kenaikan terhadap \% ekstraksi nikel saat leaching berlangsung. Pada suhu $30^{\circ} \mathrm{C}$, ekstraksi nikel mencapai $10,8 \%$, pada suhu $50^{\circ} \mathrm{C}$ ekstraksi nikel meningkat menjadi 27,8\%. Kenaikan yang cukup tinggi terjadi pada suhu $90^{\circ} \mathrm{C}$, yaitu sebanyak 95,9\% nikel terekstraksi.

Pada Gambar 3, proses leaching dilakukan dengan variasi suhu $25^{\circ} \mathrm{C}$, $50^{\circ} \mathrm{C}, 75^{\circ} \mathrm{C}$, dan $90^{\circ} \mathrm{C}$ pada kondisi operasi kecepatan pengaduk $600 \mathrm{rpm}$, 120 menit ratio solid/liquid 1:50 (2\%) dan $\mathrm{H}_{2} \mathrm{SO}_{4} 3 \mathrm{M}$. Setelah 120 menit proses pelindian, \% ekstraksi nikel dari suhu $25^{\circ} \mathrm{C}$ yang hanya $28 \%$ meningkat saat mencapai suhu $90^{\circ} \mathrm{C}$ menjadi $84 \%$.

Pada Gambar 4, proses leaching dilakukan dengan variasi suhu $45^{\circ} \mathrm{C}$, $60^{\circ} \mathrm{C}$, dan $90^{\circ} \mathrm{C}$ dengan kecepatan putar $300 \mathrm{rpm}$, konsetrasi $\mathrm{H}_{2} \mathrm{SO}_{4} 5 \mathrm{M}$, waktu 120 menit dan ratio solid liquid $25 \%$. Proses leaching yang terjadi selama 120 menit, interval suhu $45-60^{\circ} \mathrm{C}$ hanya mengalami sedikit kenaikan, namun kenaikan yang signifikan terjadi pada interval $60-90^{\circ} \mathrm{C}$ yaitu mencapai $66 \%$. Gambar 5 menunjukkan grafik pengaruh suhu terhadap \%ekstraksi nikel dengan kondisi operasi variasi suhu 30, 60, dan $85^{\circ} \mathrm{C}$, konsentrasi asam sulfat $0,1 \mathrm{M}$, ratio solid liquid $20 \%$ dalam waktu 120 menit. Dari grafik terlihat bahwa \% nikel yg terekstraki paling banyak berapa pada suhu 60 dan $85^{\circ} \mathrm{C}$.

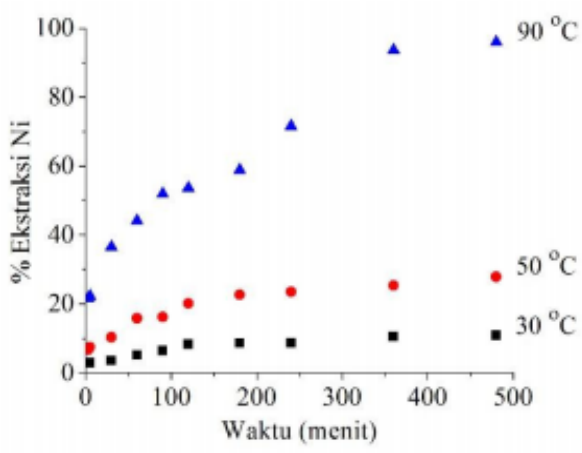

Gambar 2. Pengaruh Suhu Terhadap \% Ekstraksi Nikel

Sumber: Febriana, dkk (2018)

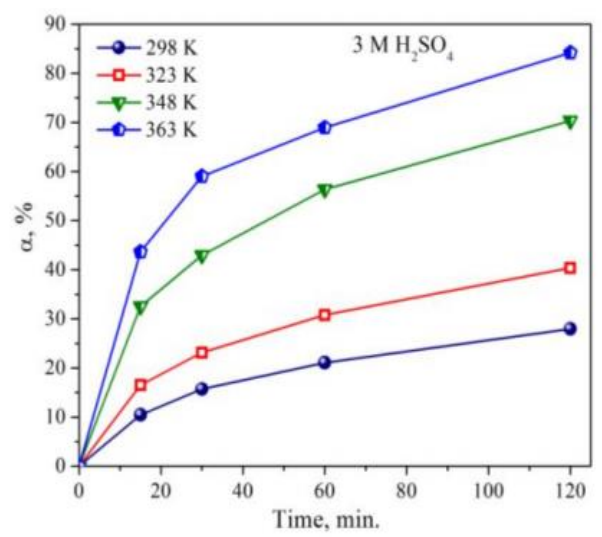

Gambar 3. Pengaruh Suhu Terhadap \% Ekstraksi Nikel

Sumber: Petrovski A, dkk (2019)

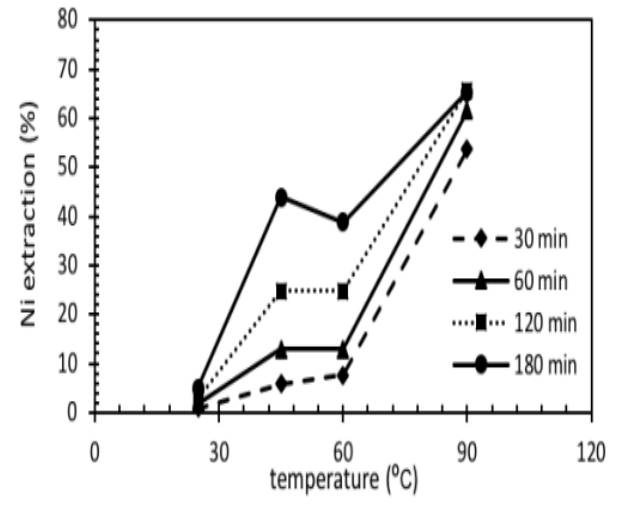

Gambar 4. Pengaruh Suhu Terhadap \% Ekstraksi Nikel

Sumber: Javanshir, dkk (2018) 


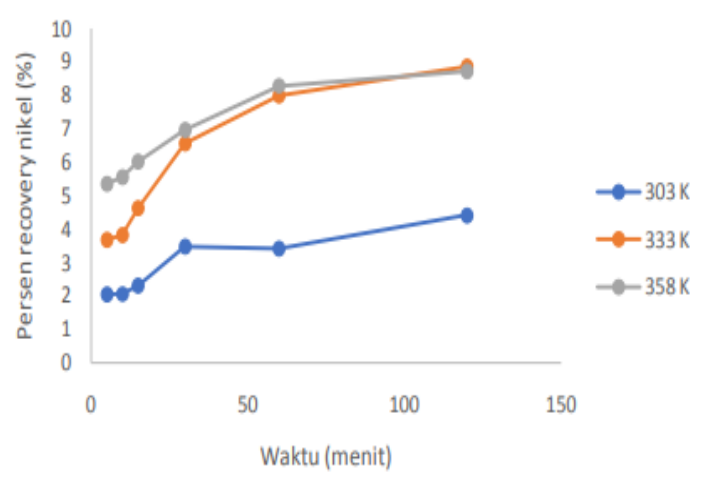

Gambar 5. Pengaruh Suhu Terhadap \% Ekstraksi Nikel

Sumber: Wanta, Kevin Cleary dkk. (2017).

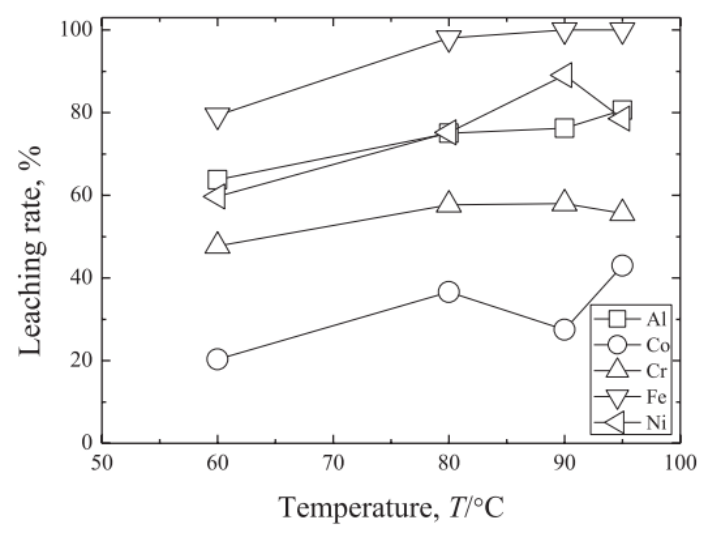

Gambar 6. Pengaruh Suhu Terhadap \% Ekstraksi Nikel

Sumber: Altansukh, Batnasan dkk. (2014)

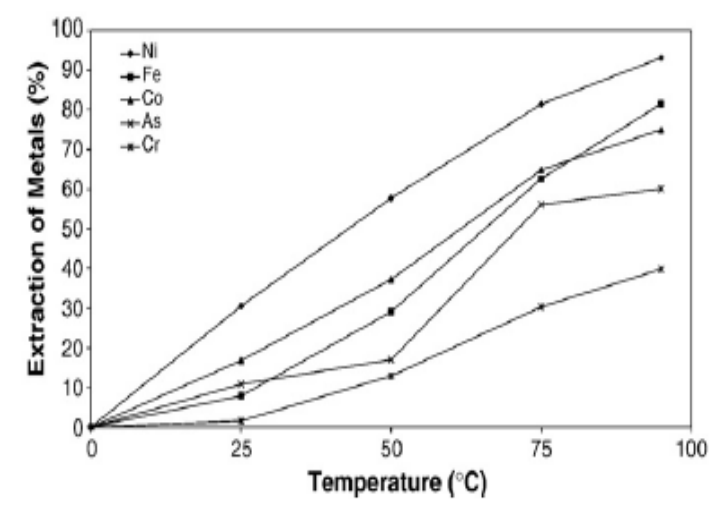

Gambar 7. Pengaruh Suhu Terhadap \% Ekstraksi Nikel

Sumber : Buyukakinci, E dan Topyaka, Y.A. (2009)

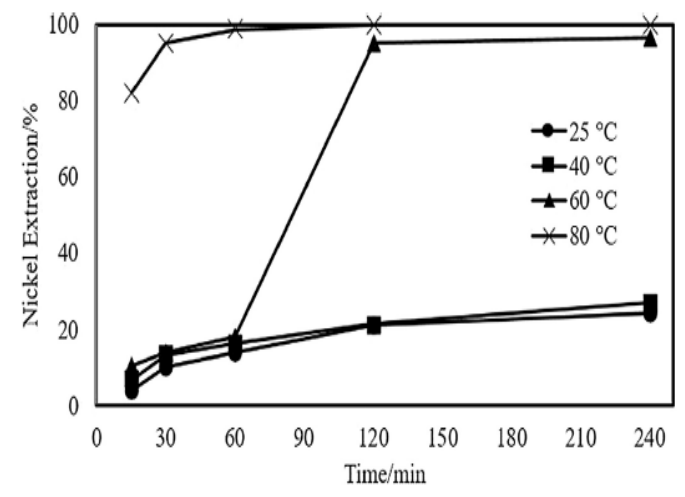

Gambar 8. Pengaruh Suhu Terhadap \% Ekstraksi Nikel

Sumber : Hosseini, dkk (2017)

Pada Gambar 6 ini khususnya saat suhu mencapai $90^{\circ} \mathrm{C}$, persen ekstraksi nikel dihasilkan sebanyak $\pm 90 \%$. Tetapi, ketika suhu meningkat menjadi $95^{\circ} \mathrm{C}, \%$ ekstraksi nikel kembali menurun. Maka dapat diketahui bahwa pada gambar 5 ini suhu optimum pelarutan nikel berada pada suhu $90^{\circ} \mathrm{C}$.

Pada Gambar 7, kenaikan suhu memiliki pengaruh yang baik untuk $\mathrm{Ni}$, terlihat dari kenaikan persen ekstraksinya yang berbanding lurus dengan kenaikan suhu. Persen ekstraksi tertinggi diraih pada suhu $95^{\circ} \mathrm{C}$, yaitu sebanyak $93,1 \%$.

Mengacu pada Gambar 8, kenaikan suhu mempengaruhi peningkatan konstanta laju reaksi serta laju perpindahan $\mathrm{H}^{+}$dan $\mathrm{Ni}^{2+}$ dalam lapisan film. Terbukti saat suhu dinaikkan dari $40^{\circ} \mathrm{C}$ menjadi $60^{\circ} \mathrm{C}$, persen ekstraksi meningkat tajam dari $24 \%$ menjadi $96 \%$. Namun hasil tertinggi diperoleh saat suhu $80^{\circ} \mathrm{C}$ dengan persen ekstraksi mendekati $99 \%$.

Pada Gambar 9 menampilkan perbandingan yang berbeda dari segi waktu. Namun, dapat dilihat bahwa variasi suhu tetap mempengaruhi walaupun dalam satuan menit. \% ekstraksi nikel tertinggi berada pada suhu $90^{\circ} \mathrm{C}$ dengan jumlah $84,8 \%$. Ekstraksi yang dihasilkan cukup tinggi walau dalam satuan menit, sehingga 
perlu dilakukan penelitian lebih lanjut mengenai pengaruh lamanya proses leaching terhadap ekstraksi nikel.

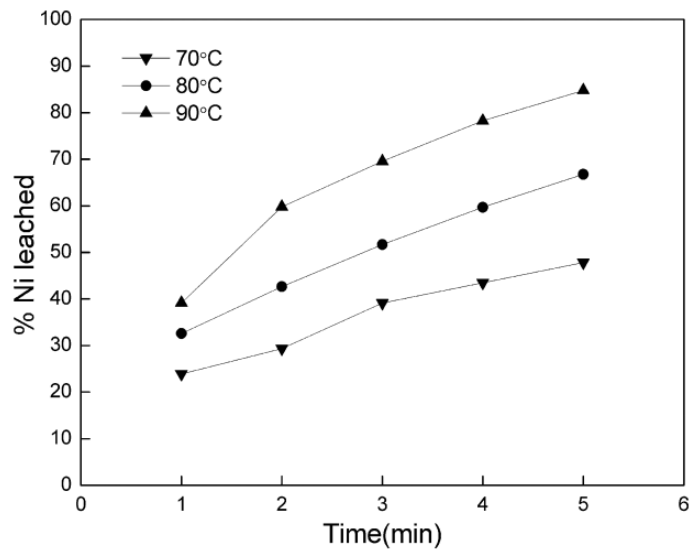

Gambar 9. Pengaruh Suhu Terhadap \% Ekstraksi Nikel

Sumber : Luo, Wei dkk. (2010)

Berdasarkan perbandingan grafik diatas, walaupun berbeda kondisi operasi, namun \% ekstraksi nikel tetap meningkat seiring kenaikan suhu. Kondisi operasi suhu yang paling optimal mengalami kenaikan signifikan yaitu dari rentang $80-90^{\circ} \mathrm{C}$. Proses leaching yang diatur pada suhu $90^{\circ} \mathrm{C}$, dapat menghasilkan nikel terlarut lebih dari $80 \%$, namun untuk mendapatkan hasil yang optimum harus tetap didukung dengan parameter kondisi operasi yang lain.

Selain parameter suhu, konsentrasi pelarut juga memengaruhi terhadap \% ekstraksi nikel pada proses leaching. Grafik yang menunjukkan pengaruh konsentrasi terhadap \% ekstraksi nikel adalah sebagai berikut.

Gambar 10 merupakan proses leaching dengan variasi konsentrasi $2 \mathrm{M}$, $5 \mathrm{M}$, dan $7 \mathrm{M}$ kondisi operasi suhu $90^{\circ} \mathrm{C}$ dan kecepatan putar 300 rpm. Kenaikan signifikan terjadi pada konsentrasi dari 2 M ke 5 M dimana ekstraksi nikel meningkat dari $15 \%$ menjadi $68 \%$. Pernyataan tersebut didukung oleh hasil penelitian Fadilah (2020) yang menyebutkan bahwa pada suhu $95^{\circ} \mathrm{C}$ dengan variasi konsentrasi pelarut 3,4 , dan 5 M ektraksi nikel tertinggi diperoleh pada konsentrasi asam sulfat 5 M sebesar 93,88\%. Begitu pula pada penelitian yang dilakukan oleh Yulianti (2020) dengan variasi $5 \mathrm{M}$ dan $6 \mathrm{M}$ pada suhu $90^{\circ} \mathrm{C}$, persen ekstraksi nikel paling besar berada pada konsentrasi asam sulfat $5 \mathrm{M}$.

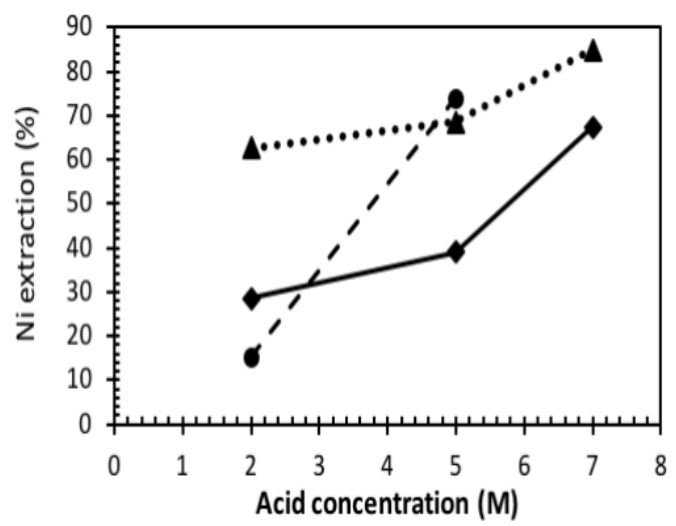

Gambar 10. Pengaruh Konsentrasi Terhadap \% Ekstraksi Nikel

Sumber: Javanshir, dkk (2018)

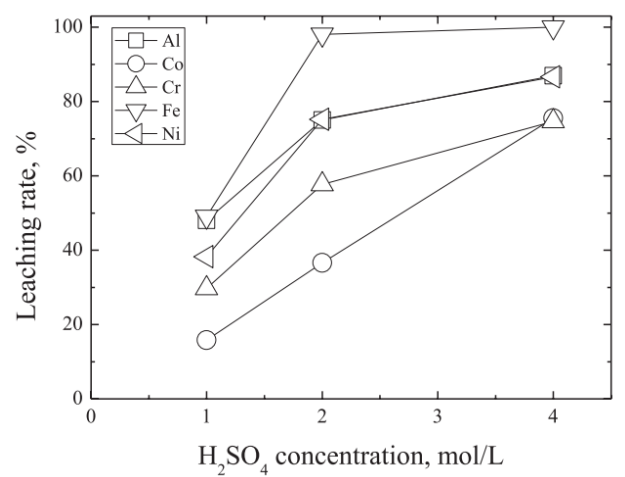

Gambar 11. Pengaruh Konsentrasi Terhadap \% Ekstraksi Nikel

Sumber: Altansukh, Batnasan dkk. 2014

Pada Gambar 11, variasi konsentrasi hampir sama dengan sebelumnya yaitu $1 \mathrm{M}, 2 \mathrm{M}$, dan $4 \mathrm{M}$ dengan kondisi operasi suhu pelindian $80^{\circ} \mathrm{C}$, waktu 120 menit dan kecepatan pengadukan $500 \mathrm{rpm}$. Ekstrak nikel yang dihasilkan meningkat seiring kenaikan konsentrasi asam sulfat 
dimana yang awalnya $38 \%$ menjadi $75 \%$ dan pada saat $4 \mathrm{M}$ menjadi $85 \%$.

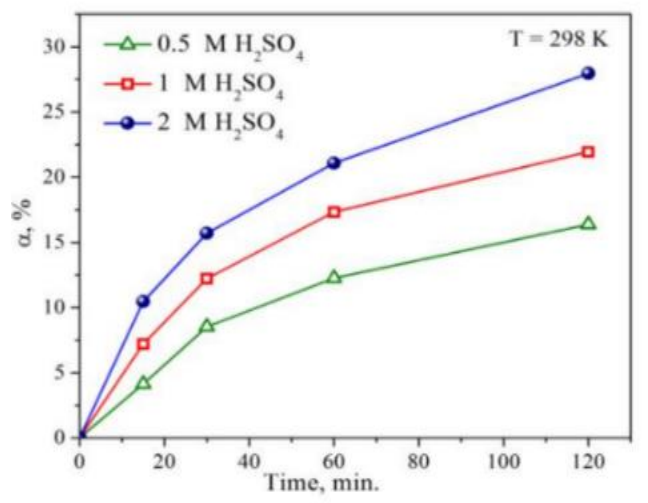

Gambar 12. Pengaruh Konsentrasi Terhadap \% Ekstraksi Nikel

Sumber: Petrovski A, dkk (2019)

Gambar 12 memperlihatkan proses leaching dengan variasi konsentrasi lebih rendah yaitu $0,5 \mathrm{M} ; 1$ $\mathrm{M}$; dan $2 \mathrm{M}$ pada suhu $25^{\circ} \mathrm{C}$ dan kecepatan putar 600 rpm. Peningkatan ekstraksi nikel terjadi dari konsentrasi $0,5 \mathrm{M}$ yaitu $16,37 \%$ menjadi $22 \%$ pada konsentrasi $1 \mathrm{M}$, dan pada konsentrasi 2 M meningkat menjadi 28\%. Kondisi ini menghasilkan persen ekstraksi yang cukup rendah. Hal tersebut dapat disebabkan karena pelindian terjadi pada suhu ruang.

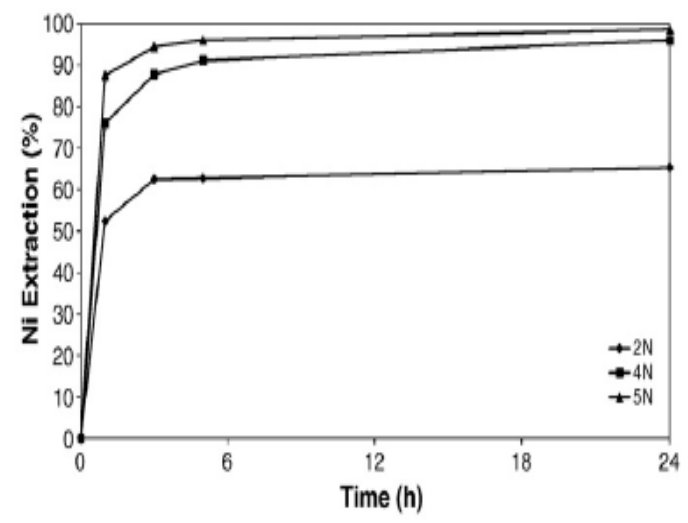

Gambar 13. Pengaruh Konsentrasi Terhadap \% Ekstraksi Nikel

Sumber : Buyukakinci, E dan Topyaka, Y.A. (2009)

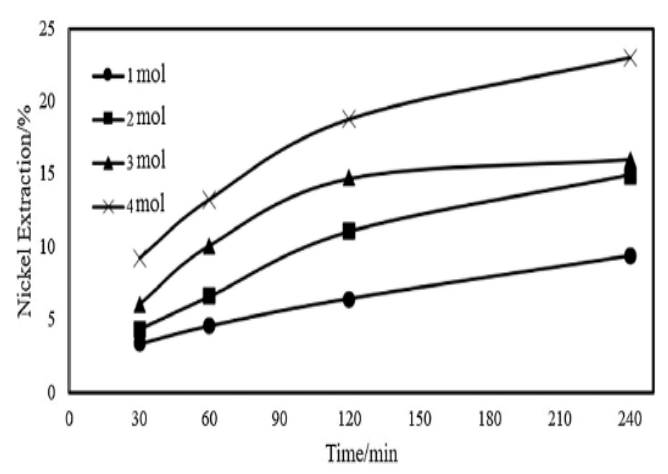

Gambar 14. Pengaruh Konsentrasi Terhadap \% Ekstraksi Nikel

Sumber : Hosseini, dkk (2017)

Gambar 13 menunjukkan variasi konsentrasi yang tidak jauh berbeda yaitu $1 \mathrm{M} ; 2 \mathrm{M}$; dan 2,5 M dengan suhu pelindian $95^{\circ} \mathrm{C}$. Grafik tersebut menjelaskan bahwa dalam waktu 1 jam pun diperoleh nilai tertinggi persen ekstaksi nikel lebih dari $80 \%$ saat konsentrasi pelarut 2,5 $\mathrm{M}$ atau $5 \mathrm{~N}$.

Konsentrasi asam yang digunakan pada Gambar 14 memiliki variasi 1-4 mol pada suhu $25^{\circ} \mathrm{C}$ dengan ukuran partikel $-250+180 \mathrm{~mm}$. Terlihat bahwa besarnya persen ekstraksi nikel sangat bergantung pada konsentrasi asam. Peningkatan konsentrasi dari 1 hingga 4 mol membawa kenaikan persen ekstraksi dari $8 \%$ menjadi $23 \%$ pada waktu 240 menit. Kenaikan ini disebabkan karena meningkatnya aktivitas ion $\mathrm{H}^{+}$dalam larutan. Berdasarkan asas Le Chatelier, peningkatan konsentrasi asam pada reaksi $\mathrm{Ni}$ yang mengandung material dengan asam akan bergeser ke kanan.

Berdasarkan perbandingan gambar pengaruh konsentrasi terhadap ekstraksi nikel, Buyukakinci dan Topkaya (2009) dalam Javanshir, dkk (2018) menyebutkan bahwa penambahan konsentrasi asam pada pelindian atmospheric dapat meningkatkan ekstraksi logam dari bijih laterit, dan menyebabkan pelarutan lebih banyak pada nikel. 


\section{SIMPULAN}

Kesimpulan dari hasil review yang telah dilaksanakan adalah terdapat pengaruh suhu dan konsentrasi terhadap proses pemisahan nikel dari logam pengotor menggunakan metode leaching, dengan perincian sebagai berikut:

1. Metode yang digunakan untuk pemisahan/pelarutan nikel dari bijih nikel laterit yaitu menggunakan metode Atmosferic Pressure Acid Leaching (APAL) karena lebih hemat energi dan lebih ekonomis.

2. Persen ekstraksi nikel terlarut meningkat seiring naiknya suhu operasi leaching.

3. Persen ekstraksi nikel terlarut meningkat seiring meningkatnya konsentrasi pelarut (asam sulfat) karena semakin tinggi konsentrasi $\mathrm{H}^{+}$semakin mudah ia melarutkan dan mengikat Nikel Oksida yang terdapat pada bijih.

\section{UCAPAN TERIMAKASIH}

Penulis mengucapkan terimakasih kepada Politeknik Negeri Bandung yang telah memberikan kesempatan dan mendanai penelitian dalam keikutsertaan Program Kreatifitas Mahasiswa (PKM) dengan nomor kontrak 538/PLI.R3/KM.07.02/2020.

\section{DAFTAR RUJUKAN}

A. Petrovski, dkk. 2019. Kinetic Models of Nickel Laterite Ore Leaching Process. International Scientific Journal "Machines Technologies Materials", year XIII, issue 11, P.P : 487-490.

Ağaçayak dan Aras. 2017. Dissolution Kinetics of Nickel from Gördes (Manisa-Turkey) Lateritic Ore by Sulphuric Acid Leaching Under Effect of Sodium Fluoride. Selcuk
University Journal of Enginering Science and Technlogy, 5(3):353354.

Altansukh, Batnasan dkk. 2014. Recovery of Nickel and Cobalt from a Low Grade Laterite Ore. Resources Processing 61 : 100-109. Büyükakinci, E. dan Topkaya, Y. A. (2009). Extraction of nickel from lateritic ores at atmospheric pressure with agitation leaching. Hydrometallurgy, 97(1-2) : 33-38.

Fadilah, Abdurrahman Hanif. 2020. Studi Pengaruh Variasi Konsentrasi Asam Sulfat Dan Persen Solid Terhadap Ekstraksi Nikel Pada Pelindian Bijih Nikel Laterit. Diploma Thesis, Universitas Teknologi Sumbawa.

Fathoni dan Mubarok. 2016. Studi Kinetika Pelindian Bijih Nikel Limonit dari Pulau Halmahera dalam Larutan Asam Nitrat. Majalah Metalurgi 1:1-63.

Febriana, Eni., dkk. 2018. Kinetika dan Mekanisme Pelindian Nikel dari Bijih Limonit : Pengaruh Waktu dan Temperatur. Metalurgi (2018) 2: 61-68.

Gustiana, dkk. 2018. Pelindian Nikel dari Bijih Limonit Low-Grade Pomalaa Menggunakan Pelarut Asam Asetat. ISSN 1693-4393 A8 : 1-7

Hosseini, S. A., Raygan, S., Rezaei, A., dan Jafari, A. (2017). Leaching of nickel from a secondary source by sulfuric acid. Journal of Environmental Chemical Engineering, 5(4): 3922-3929

Javanshir, Sepideh., dkk. 2018. Atmospheric pressure leaching of nickel from a low-grade nickelbearing ore. Physicochem. Masalah. Buruh tambang. Proses. 54 (3): 580-900.

Luo, dkk. 2010. Kinetics of saprolitic laterite leaching by sulphuric acid at 
atmospheric pressure. Elsevier Mining Engineering, 23(6):458462.

Muzayanha, dkk. 2020. Comparative Study of Various Kinetic Models on Leaching of NCA Cathode Material. Indonesian Journal of Chemistry, 20(6):1291-1300.

Safitri, Nina dkk. 2018. Recovery of nickel and cobalt as MHP from limonitic are leaching solution: Kinetics analysis and precipitate characterization. AIP Conference Procedings (020030) :1-10.

Solihin, dkk. 2014. Pelindian Bijih Nikel Laterit Sulawesi Tenggara dalam Media Asam Sulfat. ISBN 978-9798636-23-3 : 527-534.

Stopic, S dkk. (t.t). Kinetics of Sulfuric Acid Leaching of The Serbian Nickel Lateritic Ore Under Atmospheric Pressure. UDC:553.481:699.243=20 : 235244.

Wahyuadi, Johnny dan Adiyanto Naufal. 2016. Pengaruh Waktu Pemanggangan Dalam Proses Pirometalurgi Dengan Menggunakan Batubara sebagai Reduktor Terhadap Peningkatan Hasil Ekstraksi Ni Dari Batuan Saprolit. Fakultas Teknik : Universitas Indonesia.

Wanta, dkk. 2017. Studi Kinetika Proses Leaching Nikel Laterit Dalam Suasana Asam pada Kondisi Atmosferis. Lembaga Penelitian dan Pengabdian kepada Masyarakat: Universitas Katolik Parahyangan.

Wanta, dkk. 2017. Uji Validitas Model Shrinking Core terhadap Pengaruh Konsentrasi Asam Sitrat dalam Proses Leaching Nikel Laterit. Jurnal Rekayasa Proses.11 (1) : 3035.

Wanta, dkk. 2018. Studi Kinetika Proses Atmospheric Pressure Acid
Leaching Bijih Laterit Limonit Menggunakan Larutan Asam Nitrat Konsentrasi Rendah. Jurnal Rekayasa Proses 12(2): 77-84.

Yulianti, Sri. 2020. Studi Pelindian Nikel Menggunakan Asam Sulfat Dan Asam Fosfat Terhadap Selektivitas Bijih Nikel Laterit Low-Grade Pt. Antam Tbk Ubpn Sulawesi Tenggara. Diploma Thesis, Universitas Teknologi Sumbawa. 